\title{
RUWATAN ORANG JAWA KRISTEN: TINJAUAN ETIS TERHADAP PELAKSANAAN RUWATAN OLEH ORANG JAWA KRISTEN
}

\author{
Yusak Setianto ${ }^{1}$, Ferry Mahulette ${ }^{2}$ \\ ${ }^{1}$ Sekolah Tinggi Teologi Bethel Indonesia, yusaksetianto@sttbi.ac.id \\ ${ }^{2}$ Sekolah Tinggi Teologi Bethel Indonesia, ferrymahulete@gmail.com
}

\begin{abstract}
Ruwatan is a form of ceremony in Javanese society that aims to free people from bad luck and the disasters that will befall on them. Some Javanese Christians who still perform the Ruwatan ceremony. The Ruwatan ceremony itself was rejected by the church and priests, especially the Javanese Christian Church/Gereja Kristen Jawa (GKJ). This article itself aims to understand the Ruwatan model by Javanese Christians and to review it in a christian ethics related to the implementation of Ruwatan by Javanese Christian. The method used is a qualitative method with a field observation approach. The speakers were Javanese Christians who participated in Ruwatan, cultural practitioner, and priests of GKJ. We found the fact that there are two models of Ruwatan done by Javanese Christians. We give the terms with Javanese Christians A and B. Javanese Christians A do Ruwatan as in general, namely the style of Yogyakarta and Surakarta. While the Javanese Christian B performs Ruwatan that has been contextualized in the form of bidston/pandonga worship. The Church and GKJ Priests themselves support the Ruwatan model carried out by Javanese Christian B which presents Jesus as the Human Guardian. In conclusion after being reviewed in christian Ethics, the Ruwatan carried out by Javanese Christian A cannot be justified in terms of both the motive and the action. Contrary, the Javanese Christianity B can be accepted and implemented because it is not in conflict with the Bible.
\end{abstract}

Keywords: ruwatan; javanese christians; bidston/ pakempalan pandonga; javanese christian church; christian ethics

\begin{abstract}
Abstrak
Ruwatan merupakan suatu bentuk upacara di masyarakat Jawa yang bertujuan untuk membebaskan manusia dari nasib buruk maupun malapetaka yang akan menimpa dirinya. Tidak sedikit orang Jawa Kristen yang masih melakukan upacara Ruwatan. Upacara Ruwatan sendiri ditolak pelaksanaannya oleh gereja dan pendeta, khususnya Gereja Kristen Jawa (GKJ). Artikel ini sendiri bertujuan untuk memahami model Ruwatan yang dilakukan orang Jawa Kristen serta meninjauan nya secara etika Kristen terkait pelaksaan Ruwatan oleh orang Jawa Kristen. Metode yang digunakan ialah metode kualitatif dengan pendekatan observasi lapangan. Narasumbernya merupakan Orang Jawa Kristen peserta Ruwatan, budayawan, serta pendeta GKJ. Peneliti menemukan fakta bahwa terdapat dua model Ruwatan yang dilakukan oleh orang Jawa Kristen. peneliti memberi istilah dengan Orang Jawa Kristen A dan B. Orang Jawa Kristen A melakukan Ruwatan seperti pada umumnya yaitu bergaya Yogyakarta dan Surakarta. Sedangkan orang Jawa Kristen B melakukan Ruwatan yang telah dikontekstualisasikan dalam bentuk ibadah bidston/ pakempalan pandonga. Gereja dan Pendeta GKJ sendiri mendukung model Ruwatan yang dilakukan oleh orang Jawa Kristen B yang mana menghadirkan Yesus sebagai Juru Ruwat Manusia. Kesimpulannya setelah ditinjau secara etika Kristen, maka Ruwatan yang dilakukan oleh orang Jawa Kristen A tidak dapat dibenarkan baik secara motif dan tindakan pelaksanaannya. Sebaliknya, Ruwatan orang Jawa Kristen B dapat diterima dan dilaksanakan karena tidak bertentangan dengan Alkitab.
\end{abstract}

Kata Kunci: ruwatan; orang jawa kristen; bidston/ pakempalan pandonga; gereja kristen jawa; etika kristen 


\section{PENDAHULUAN}

Manusia dalam siklus kehidupannya tidak dapat dipisahkan dengan Budaya. Salah satunya budaya yang masih menjadi realitas hidup orang Jawa ialah Upacara Ruwatan Sukěrta. Ruwatan Sukěrta sendiri merupakan upacara penyucian dan pembersihan dari kondisi yang kotor/ tidak ideal.

Peneliti menemukan bahwa tidak sedikit orang Jawa Kristen yang mengikuti dan melakukan Ruwatan baik secara pribadi atau massal. Dalam temuan itu sendiri terdapat juga perbedaan dalam memahami tradisi Ruwatan, baik pandangan yang menerima maupun menolak.

$$
\text { Pendapat yang menerima }
$$

pelaksanaan tradisi tersebut menyatakan tradisi tersebut merupakan bagian dari kebudayaan Jawa yang memiliki kaitan dan persamaan dengan kebenaran Firman Tuhan. Hal ini didapat bedasarkan beberapa pendapat para ahli yang akan peneliti paparkan.

Menurut Hari Kustono ttradisi Ruwatan memiliki nilai - nilai atau makna Kristiani seperti keselamatan, nilai etika hubungan suami-istri, manusia berhadapan dengan waktu, unsur penyucian dan pembersihan, sesaji, dan kidung/mantra, sehingga ketika dimaknai dengan benar unsur tahayul/mitos menghilang dan manusia dengan segala permohonannya akhirnya berhadapan dengan Tuhan Yesus sebagai Sang Penyelamat. ${ }^{1}$
Ignatius Joko Suyanto berpendapat konsep keselamatan dalam tradisi Ruwatan memberikan dasar kepada soteriologi Kristen. ${ }^{2}$ Jika kedua hal tersebut dipadukan terbentuk soteriologi dengan dua dimensi yang membantu penghayatan iman dan pewartaan keselamatan Yesus Kristus yang kontekstual dalam konteks budaya Jawa. Selain itu dalam tradisi Ruwatan terdapat pokok - pokok keyakinan orang Jawa yang dapat menjadi lahan tumbuh kembangnya iman Kristen.

Namun justru terdapat perbedaan yang nampak dari pandangan gereja terhadap tradisi Ruwatan. Peneliti menemukan bahwa gereja memiliki pandangan yang berbeda dengan pemaparan yang peneliti telah paparkan sebelumnya. Gereja secara terus terang menolak keberadaan tradisi Ruwatan itu sendiri. Berikut peneliti akan memaparkan beberapa pandangan yang menolak tradisi Ruwatan jika dilakukan oleh Orang Jawa Kristen.

Dalam Jurnal Kurios dijelaskan mengenai sikap gereja yang menolak tradisi Ruwatan, karena bagi gereja sendiri keselamatan sudah terdapat di dalam Yesus Kristus sehingga tidak perlu lagi untuk mencari keselamatan di tempat lain serta adanya unsur- unsur yang menyimpang dari kebenaran Alkitab. ${ }^{3}$

Hal ini senada dengan yang disampaikan oleh Pdt. Lukas Eko Sukoco,M.Th yang merupakan Badan Pengkajian Budaya Jawa (BaPekJa) Gereja 
Kristen Jawa dan juga Gembala Sidang Gereja Kristen Jawa, Purworejo. Beliau memaparkan bahwa Gereja Kristen Jawa tidak pernah menyentuh tradisi ini selama 25 tahun terakhir. Gereja Kristen Jawa menolaknya karena terdapat unsur-unsur yang sinkritisme yang bertentangan dengan kebenaran Alkitab. ${ }^{4}$

Selain itu realitas yang peneliti temukan ialah masyarakat Jawa yang ada memiliki dua identitas yang saling melekat yang penulis paparkan sebagai orang Jawa Kristen. Orang Jawa Kristen merupakan orang dengan memiliki adat-istiadat dan tradisi Jawa yang melekat dalam kehidupannya kemudian ia berada dalam sebuah komunitas atau persekutuan Kristen, yaitu gereja. Orang tersebut percaya kepada Kristus dan hidup di dalam ajaran dan kebenaran Firman Tuhan. Identitas yang mereka miliki sebagai seorang Jawa Kristen tidak dapat dilepaskan ataupun dipisahkan satu dengan yang lainnya. Identitas ini telah menjadi bagian yang berakar kuat dalam kehidupan orang Jawa Kristen.

Menariknya peneliti menemukan fakta tentang pelaksanaan tradisi Ruwatan di lingkungan masyarakat Jawa pada masa kini. Faktanya ialah bahwa tidak sedikit orang Jawa Kristen yang melakukan tradisi Ruwatan. Data ini peneliti dapatkan ketika menghadiri Ruwatan Bersama XXVII 2018 di Pendopo Taman Siswa, Yogyakarta. Sebagian besar peserta yang ikut dalam acara Ruwatan Bersama merupakan orang Kristen.

Temuan dilapangan bagi peneliti merupakan suatu realita yang mengejutkan, karena orang Jawa Kristen merupakan dua identitas. Di satu pihak sebagai orang Jawa yang budaya dan adat-istiadatnya melekat dalam kehidupannya, serta tradisi Ruwatan dipandang sebagai sebuah tradisi yang harus dilakukan karena dipercaya keberadaannya. Namun dipihak yang lain sebagai seorang Jawa yang beragama Kristen, mereka pun hidup dalam kepercayaan kepada Kristus dan hidup didalam kebenaran Firman Tuhan melalui persekutuan gereja. Sedangkan gereja baik secara lembaga dan para pemimpinnya menolak tradisi Ruwatan karena terdapat unsur yang bertentangan dengan kebenaran itu sendiri.

Dengan melihat permasalahan yang terjadi dikalangan orang Jawa Kristen pada masa kini maka peneliti terinspirasi untuk mengangkat penelitian mengenai pelaksanaan tradisi Ruwatan oleh orang Jawa Kristen. Peneliti menggali bagaimana orang Jawa Kristen dalam melaksanakan tradisi Ruwatan, serta melihat dari tinjauan etika Kristen terhadap pelaksanaan Ruwatan oleh orang Jawa Kristen.

\section{METODE PENELITIAN}

Peneliti sendiri dalam hal ini menggunakan pendekatan kualitatif yang penelitiannya berlandaskan pada pasca- 
positivisme. ${ }^{5}$ Format penelitian kualitatif ini menggunakan metode deskriptif. Metode ini ialah pencarian fakta dengan interpretasi yang tepat atau dengan kata lain penelitian ini mempelajari masalah-masalah dalam masyarakat, serta kebiasaan yang berlaku dalam masyarakat dalam situasi tertentu. ${ }^{6}$ Menurut Nana Syaodih, penelitian deskriptif merupakan metode untuk mendeskripsikan dan menggambarkan fenomena-fenomena yang ada, baik bersifat alamiah maupun rekayasa manusia,yang lebih memperhatikan mengenai karakteristik, kualitas, keterikatan antar kegiatan. Selain itu, penelitian deskriptif tidak memberikan perlakuan, manipulasi atau pengubahan pada variabel-variabel yang diteliti, melainkan menggambarkan suatu kondisi yang adanya. Dalam penelitian ini pengumpulan data menggunakan metode observasi, wawancara dan dokumentasi.

Peneliti mengambil sampel data dari beberapa acara Ruwatan massal yang berada di Surakarta, Yogyakarta dan Taman Mini Indonesia Indah. Informannya berjumlah 30 orang yang terdiri dari orang Jawa Kristen peserta Ruwatan, budayawan, dalang ruwat, dan Pendeta Gereja Kristen Jawa.

Setelah data dikumpulkan, tahap selanjutnya adalah analisa data. ${ }^{7}$ Analisa data dalam penelitian kualitatif sendiri bersamaan dengan proses pengumpulan data. Diantaranya terdapat tiga tahap model analisis data, yaitu reduki data, penyajian data, dan verifikasi data. ${ }^{8}$ Analisa data kualitatif sendiri merupakan upaya yang dilakukan dengan jalan bekerja dengan data, mengorganisir data, memilah-milah menjadilan satuan yang dapat dikelola, mensistensikannya, mencari dan menemukan pola, menentukan apa yang penting dan apa yang dipelajari, dan memutuskan apa yang dapat diceritakan kepada orang lain. ${ }^{9}$

\section{PEMBAHASAN}

Mayoritas orang Jawa mengetahui mengenai tradisi Ruwatan sukěrta, tetapi tidak semuanya pernah mengikuti/ melakukan tradisi Ruwatan sukěrta. Beberapa alasan yang ada karena tidak ada biaya untuk mengadakannya atau tidak ada penyelenggaraan secara massal. Selain itu peneliti juga menemukan tidak sedikit orang Jawa Kristen yang mengikuti tradisi Ruwatan sukěrta, yaitu secara massal. Data ini peneliti peroleh dengan menjumpai pelaku Ruwatan pada acara Ruwatan sukěrta yang diselenggarakan diberbagai tempat. Banyaknya orang Jawa Kristen melakukan Ruwatan sukérta berkaitan dengan keyakinan mereka sebagai orang Jawa yang memiliki anak sukěrta harus diruwat dan untuk melestarikan tradisi Ruwatan.

Selain itu, peneliti menemukan adanya perbedaan pandangan dalam memaknai tradisi Ruwatan sukěrta. 
Perbedaan ini ditemukan dari berbagai narasumber yang diwawancara. Untuk memudahkan pembahasan dalam deskripsi hasil penelitian, peneliti memberikan identitas kepada kedua kelompok yaitu orang Jawa Kristen A dan orang Jawa Kristen B. ${ }^{10}$

1. Orang Jawa Kristen A

$$
\text { Orang Jawa Kristen A }
$$
memiliki pandangan bahwa keyakinan atau iman Kristen harus dipisahkan dengan kebudayaan dan tradisi.

Mereka

melakukan/mengikuti Ruwatan sukěrta secara massal tanpa mencampurkan iman mereka didalamnya. Ruwatan sukěrta yang mereka ikuti sama dengan Ruwatan yang dilakukan oleh orang Jawa pada umumnya.

2. Orang Jawa Kristen B

$$
\text { Orang Jawa Kristen B }
$$
memiliki pandangan bahwa kebudayaan dan tradisi harus diterangi atau diberi makna Injil Kristus di dalamnya. Mereka tidak melakukan Ruwatan sukěrta seperti pada umumnya tetapi memodifikasinya atau dikemas secara Kristen dalam bentuk ibadah persekutuan doa yang terkadang disebut dengan bidston $^{11}$ atau Pakempalan Pandungo. ${ }^{12}$ Untuk pembahasan selanjutnya peneliti sendiri lebih menggunakan istilah

\begin{abstract}
Pakempalan Pandungo yang menggambarkan persekutuan doa yang didalamnya terdapat permintaan keluarga terkait mengenai permasalahan (sukěrta) mereka.
\end{abstract}

Tak dapat di sangkal bahwa kebudayaan merupakan sesuatu yang melekat dalam diri manusia dan tidak dapat dipisahkan keberadaannya. Menurut Koentjaraningrat kebudayaan merupakan keseluruhan manusia dari kelakukan dan hasil kelakuan yang teratur oleh tata kelakuan yang di dapatkannya dengan belajar dan yang semuanya tersusun dalam kehidupan masyarakat. ${ }^{13}$ Selain itu kebudayaan merefleksikan dan sekaligus membentuk nilai-nilai dan pandangan manusia terhadap dunia ini, sehingga kebudayaan bukan saja melekat dan berkaitan dengan kehidupan manusia tetapi dapat mempengaruhi cara pandang manusia. $^{14}$

Orang percaya harus memahami kebudayaan dengan benar dalam perspektif kebenaran Firman Tuhan. Orang percaya harus melihat kembali budaya dari perspektif Alkitab (seperti Yesus dan Paulus). Faktanya Alkitab ditulis dalam konteks masyarakat dan budaya lokal setempat seperti yang dikatakan Alous Piers, "Kekristenan dapat berkembang dan menyebar luas jika dapat masuk dan berakar didalam budaya lokal yang ada."15 
Sikap Orang Jawa Kristen menurut Teori Richard Niehbur

Peneliti menemukan fakta bahwa orang Jawa Kristen A cenderung memisahkan antara iman Kristen dengan kebudayaan Jawa yang ada. Sikap seperti ditemukan diberbagai jawaban narasumber, mayoritas menyatakan tidak mempermasalahkan pemisahan iman Kristen dengan budaya Jawa karena keduanya berbeda. Budaya sudah ada lebih dahulu sebelum agama berkembang di Indonesia. Peneliti melihat hal ini tidak bisa dikatakan sesederhana itu karena keyakinan berkembang dan masuk didalam setiap kebudayaan di dunia. Keyakinan memberikan sebuah warna di dalam kebudayaan lokal yang ada, sehingga manusia, budaya, dan keyakinan tidak dapat dilepaskan satu dengan lainnya.

Sikap yang dimiliki oleh Orang Jawa Kristen A ini termasuk dalam Teori Niebuhr yaitu pandangan Yesus dan Kebudayaan dalam paradoks (merupakan pemisahan antara iman dan kebudayaan). Dengan kata lain orang Kristen berada dalam dua suasana yaitu berada dalam kebudayaan dan sekaligus berada dalam anugrah Allah dalam Kristus. Oleh karena itu orang Kristen terhimpit oleh dua suasana yaitu hidup dalam iman dan hidup dalam kebudayaan. ${ }^{16}$ Selain itu juga Richard Niebuhr mengatakan bahwa manusia tidak dapat seperti amfibi: hidup dalam anugrah Allah dan sekaligus dalam kebudayaan.
Karena kedua lingkungan ini terpisah dan tidak saling berhubungan. ${ }^{17}$

Menurut peneliti sikap/ pandangan yang dimiliki oleh orang Jawa Kristen B merupakan sikap yang bijak. Mereka menerima kebudayaan yang ada tetapi memberikan warna baru didalam kebudayaan tersebut seperti pandangan Verkuyl sebagai jawaban atas persoalanan iman Kristen dengan budaya yang ada. Tradisi Ruwatan yang dilakukan oleh orang Jawa Kristen B sudah mengalami sebuah pembaharuan budaya atau yang disebut juga dengan rekulturasi yang mana disaring unsur-unsur yang dapat diterima oleh iman Kristen dan menghilangkan unsur yang bertentangan.

Pandangan/ sikap yang dilakukan oleh orang Jawa Kristen B merupakan sikap yang kelima dari teori Niebuhr, yaitu Yesus pembaru budaya. Sikap ini dianggap tepat oleh Niebuhr. Begitu pula yang dikatakan Verkuyl bahwa orang Kristen dalam sejarah abad-abad yang panjang tidak menyetujui keempat sikap tersebut baik dalam teori maupun dalam praktiknya. Mereka tidak bersedia menyerah kepada kebudayaan karena mereka memahami kebudayaan mempunyai kelemahan-kelemahan. Mereka juga menolak takluk kepada kebudayaan yang dipaksakan gereja sebab kebudayaan yang dipaksakan gereja selalu berbentuk sintesa antara kerajaan Allah dan kerajaan dunia, serta ada kecenderungan memandang kebudayaan yang masih berdosa ini 
dianggap suci jika berada di bawah gereja.

Tetapi pandangan kerajaan Allah telah diwujudkan dalam kebudayaan yang diciptakan gereja, tidak benar. ${ }^{18}$

\section{Pengambilan Keputusan Etis bedasarkan Etika Deontologis}

Sejatinya tradisi budaya masyarakat yang ada tidak boleh bertentangan dengan Injil. Injil harus menjadi sentral dalam kehidupan manusia dalam berbudaya. Peneliti sendiri sudah memaparkan mengenai bagaimana sikap yang harusnya diambil ketika menghadapi permasalahan antara Kristus dan kebudayaan. Kristus sendiri harus memperbaharui kebudayaan yang ada. Sehingga dalam budaya itu ada penyaringan untuk membuang yang bertentangan dan mempertahankan yang baik tetapi fokusnya ialah Kristus.

Berdasarkan observasi lapangan, tradisi Ruwatan yang dilakukan oleh orang Jawa Kristen A masih kental dengan budaya yang ada. Ruwatan yang dilakukan merupakan Ruwatan dengan pakem-pakem murwakala dengan gaya Yogyakarta dan Surakarta. Dalam praktiknya juga tidak ada penyesuaian dengan nilai-nilai Iman Kristen. Sikap/ pandangan orang Jawa Kristen A sendiri tidak menganggap itu sebagai masalah, karena mereka memisahkan iman dan kebudayaan. Sikap itu sudah peneliti bahas sebagai sikap dualis yang memisahkan Kristus dengan budaya.
Peneliti menggunakan metode deontologi untuk mengambil keputusan dalam masalah pelaksanaan Ruwatan oleh orang Jawa Kristen. Sebuah tindakan dikatakan benar/baik karena tindakan tersebut dilaksanakan berdasarkan kewajiban yang harus dilaksanakan dan dalam etika Kristen kewajiban tersebut tidak berlawanan dengan kewajiban yang diperintahkan dalam hukum Tuhan. Metode deontologi memegang prinsip-prinsip, aturan, dan nilai yang dipakai ialah bedasarkan kebenaran Firman Tuhan (Alkitab).

Bedasarkan masalah yang sedang hadapi yaitu mengenai adanya pelaksanaan tradisi Ruwatan oleh orang Jawa Kristen maka peneliti memilih teori kelima tentang sikap gereja dan kebudayaan sebagai pedoman untuk menjawab permasalahan ini. Alkitab menyatakan bahwa segala sesuatu yang diciptakan Tuhan baik adanya, tetapi karena dosa menjadi rusak. Kerusakan tersebut dapat diperbaharui kembali melalui karya Kristus di dalam dunia.

Dengan demikian, berdasarkan segala pertimbangan secara teologis dan etis maka pandangan orang Jawa Kristen A tidak lagi di lakukan oleh orang Kristen. Sebaliknya seharusnya orang Kristen mengikuti pandangan orang Jawa Kristen B yang menggelar acara bidston/ pakempalan pandonga yang di isi dengan nilai-nilai iman Kristen dan liturgi Kristen. Untuk 
melestarikan tradisi Ruwatan orang Jawa Kristen tentunya dapat mengajarkan kepada generasi selanjutnya dengan menonton pertunjukannya bukan mengikutinya. Sehingga tetap memenuhi unsur pelestarian budaya lokal yang ada.

\section{KESIMPULAN}

Pelaksanaan Tradisi Ruwatan oleh Orang Jawa Kristen ditemukan dua kelompok yang melaksanakan dengan cara yang berbeda. Orang Jawa Kristen A melaksanakan tradisi Ruwatan seperti pada umumnya, yaitu mengikuti pakem-pakem yang ada. Sedang rrang Jawa Kristen B telah mengupayakan acara bidston/ pakempalan pandonga yang diisi dengan liturgi dan nilai iman Kristen.

Hal yang mendasari orang Jawa Kristen melaksanakan Tradisi Ruwatan pun memiliki perbedaan. Orang Jawa Kristen A melaksanakannya karena terdapat beberapa alasan seperti merasa dihantui oleh Batara Kala sebagai simbol bahaya. Mereka menerima pesan dari leluhur, merasa telah melanggar pantangan yang ada, adanya tekanan sosial serta upaya pelestarian budaya. Sedangkan orang Jawa Kristen B dalam pelaksanaan acara bidston/ pakempalan pandonga didasarkan kepada ucapan syukur kepada Tuhan atas segala yang telah diberi.

Peneliti membandingkan pelaksanakan tradisi Ruwatan oleh orang Jawa Kristen dengan orang Jawa pada umumnya. Orang Jawa Kristen A melaksanakan tradisi Ruwatan seperti orang Jawa pada umumnya karena mengikuti Ruwatan secara massal, sedangkan orang Jawa Kristen B melakukan acara bidston/ pakempalan pandonga yang sangat berbeda dengan Ruwatan pada umumnya. Acara bidston/ pakempalan pandonga telah diisi liturgi Kristen dan nilai yang sesuai dengan Iman Kristen.

Dalam perspektif etika Kristen mengenai pengambilan keputusan etis terhadap pelaksanaan tradisi Ruwatan oleh Orang Jawa Kristen. Peneliti sendiri menimbang secara teleologis bahwa tradisi Ruwatan yang dilakukan oleh orang Jawa Kristen A merupakan sebuah kesia-siaan serta hal yang tidak ada gunanya, karena pada dasarnya orang percaya telah diruwat oleh Yesus Kristus sebagai Juru Ruwat Manusia yang telah selesai di golgota. Sebaiknya Orang Jawa Kristen melakukan acara bidston/ pakempalan pandonga yang mana mengisinya dengan ucapan syukur dengan liturgi Kristen yang ada. Sedangkan jika menimbang upaya pelestarian budaya, maka banyak sarana lain yang dapat digunakan untuk melestarikan.

\section{DAFTAR PUSTAKA}

Badriyah, Huriyyah. Kumpulan Contoh Sukses dan Tembus pengajuan Proposal : Panduan Wajib Proposal untuk Pribadi Kelompok Pengusaha dan Perusahaan. Jakarta: Pusat 
Pengembangan Pendidikan non-

Formal dan Informal Regional.

Fore, William F. Para Pembuat Mitos.

Jakarta: BPK Gunung Mulia, 2000.

J.Verkuyl. Etika Kristen Kebudayaan.

Jakarta: BPK Gunung Mulia, 1960.

Koentjaraningrat. Kebudayaan Jawa. Balai

Pustaka: Jakarta, 1980.

Kristriyanto. "Yesus Kristus Juru Ruwat

Manusia : Sebuah Pendekatan

Semiotika dalam Gereja Kristen

Jawa.” Jurnal Kurios, 2018: 40.

Kustono, Hari. "Ruwatan : Tinjauan

Alkitabiah." Studia Philosophica et

Theologica: Jurnal Teologi Filsafat.

Maret 2016: 63-74.

Margono, S. Metode Penelitian Pendidikan.

Jakarta: Rineka Cipta, 2004.
Mariani, Lies. "Ritus Ruwatan Murwakala

di Surakarta." Umbara: Jurnal

Antropologi Indonesia. Juli 2016:

54-55.

Nazir, Mohamad. Metode Penelitian.

Bogor: Ghalia, 1988.

Niebuhr, H.Richard. Kristus dan

Kebudayaan. Jakarta: Petra Jaya, 1954.

Pieris, Aloysius. Berteologi dalam Konteks

Asia. Yogyakarta: Penerbit

Kanisius, 1996.

Sugiyono. Metode Penelitian Kuantitatif,

Kualitatif, dan Kombinasi.

Bandung: Alfabeta, 2014.

Suyanto, Iganatius Joko. "Ruwatan Jawa dalam Perspektif Iman Kristiani."

Jurnal Teologi. Mei 2014: 60-75.

\footnotetext{
${ }^{1}$ Kustono, Hari, Ruwatan : Tinjauan Alkitabiah, Studia Philosophica et Theologica : Jurnal Teologi Filsafat (Maret 2016), 74-77.

${ }^{2}$ Suyanto, Ignatius Joko. Ruwatan Jawa Dalam Perspektif Iman Kristiani. Jurnal Teologi Universitas Atma Jaya (Mei 2014), 63-74.

${ }^{3}$ Kristriyanto, "Yesus Kristus Juru Ruwat Manusia : Sebuah Pendekatan Semiotika dalam Gereja Kristen Jawa,” Kurios: Jurnal Teologi dan Pendidikan Agama Kristen Vol.4, No. 1 (April, 2018), 53.

${ }^{4}$ Hasil Wawancara dengan Pdt. Lukas Eko Sukoco, M.Th melalui Pesan Whatsapp pada Rabu, 19 September 2018.

${ }^{5}$ Sugiyono, Cara Mudah Menyusun Skripsi, Tesis dan Disertasi (Jakarta: Alfabeta, 2014), 24.

${ }^{6}$ Moh. Nazir, Metode Penelitian (Bogor: Ghalia, 1988), 63-64.

${ }^{7}$ Huriyah Badriyah, Kumpulan Contoh Sukses dan Tembus Pengajuan Proposal : Panduan Wajib Proposal untuk Pribadi Kelompok Pengusaha dan Perusahaan, 21.

${ }^{8}$ Margono, Metode Penelitian Pendidikan, 144.

${ }^{9}$ Moeleong. Metode Penelitian Kualitatif, 248.

${ }^{10}$ Penggunaan Istilah 'Orang Jawa Kristen A' dan 'Orang Jawa Kristen B' diberikan oleh peneliti kepada orang Jawa Kristen yang mengikuti Tradisi Ruwatan Sukerta pada umumnya dan juga kepada orang Jawa Kristen yang melakukan tradisi Ruwatan dalam kemasan Kristen yang diberi nama pakempalan pandonga. Orang Jawa Kristen A sendiri merupakan orang Kristen di wilayah Jawa Tengah dan Yogyakarta. Sedangkan orang Jawa Kristen B merupakan warga gereja Sinode Gereja Kristen Jawa.

${ }^{11}$ Bidston merupakan istilah dalam bahasa belanda yang merujuk kepada persekutuan doa. Istilah ini sendiri terdapat di gereja-gereja yang beraliran protestan khususnya Gereja Kristen Jawa.
} 
${ }^{12}$ Pakempalan Pandungo merupakan istilah dalam bahasa jawa yang merujuk kepada persekutuan doa. Istilah ini hanya terdapat di gereja Kristen Jawa, yang artinya ialah pakempalan berarti berkumpul dan pandonga berarti berdoa, sehingga berarti perkumpulan/ persekutuan doa. Hal ini disampaikan oleh Pdt. Kristriyanto,M.Th dalam wawancaranya 6 Maret 2018.

${ }^{13}$ Koentjaraningrat, Pengantar Antropologi (Jakarta: Balai Pustaka, 1969), 24.

${ }^{14}$ William F.Fore, Para Pembuat Mitos (Jakarta: BPK Gunung Mulia, 2000), 2.

${ }^{15}$ Aloysius Pieris, Berteologi dalam Konteks Asia (Yogyakarta: Penerbit Kanisius,1996), 195-196.

${ }^{16}$ Niebuhr, Kristus dan Kebudayaan, 171-172.

${ }^{17}$ Ibid., 186.

${ }^{18}$ Verkuyl, Etika Kristen Kebudayaan, 49. 